\title{
HISTORICAL PERSPECTIVES OF THE AMERICAN ASSOCIATION FOR THORACIC SURGERY
}

\author{
FREDERICK TAYLOR LORD (1875-1941)
}

$F^{i}$ ed Lord, fourteenth president of The American Association for Thoracic Surgery and second non-surgeon elected to that position, was born in Bangor, Maine, January 16, 1875. Brought up in Lexington, Massachusetts, he attended the local schools in preparation for Harvard, where he acquired an excellent reading knowledge of French and German, as well as a BA, in 1897. Three years later he received his MD after 3 years at Harvard Medical School. He served as a medical house officer at the Massachusetts General Hospital (19001902) and remained on the medical staff of that hospital until his death 40 years later. In tune with the times, he served the hospital and school largely without pay, making a comfortable living in what proved to be a very large private practice dealing principally with diseases of the pleura, lungs, and bronchi. So well, in fact, did he integrate practice and teaching that in 1905 he was asked by Sir William Osler to prepare a section on influenza for his system of medicine. Two years later Osler sought him out again, this time to deal with diseases of the pleura. In 1915 Lord published the first edition of his principal work, Diseases of Bronchi, Lungs, and Pleura, dedicated to his mentor, Reginald Fitz. Thoroughly brought up to date editorially 10 years later, it remains an important work in this field. Quite early in his clinical career, he persuaded J. Homer Wright, distinguished professor of pathology at the Massachusetts General Hospital, to give him a small cubbyhole in his laboratory where, despite the demands of clinical practice, he always had some piece of research in progress. Clearly at this stage he was greatly influenced by Homer Wright and Reginald Fitz.

In due course he was given more suitable laboratory space where, with Robert Nye, he produced timely studies of the biology of the pneumococcus just as type-specific antipneumococcic serum therapy appeared on the scene in 1913. For the next 20 years he was a leader and recognized authority in the clinical application of this lifesaving mode of therapy for pneumonia until the advent of sulfonamide chemotherapy, followed by antibiotics. A charming vignette has been preserved by W. G. Austen at The Massachusetts General Hospital of Lord at a bedside on his busy round of house calls carrying in his pocket a small box containing two or three laboratory mice, which he could inject intraperitoneally with small amounts of the patient's sputum and be rewarded next

J Thorac Cardiovasc Surg 1998;116:1088-9

Copyright (C) 1998 by Mosby, Inc.

$0022-5223 / 98 \$ 5.00+0 \quad \mathbf{1 2 / 5 4 / 9 3 4 7 0}$ morning by a flourishing growth of type-specific pneumococci in the mouse's peritonitis. The psychologic benefit to the patient with pneumonia has not been calculated.

As a pioneer in the use of antiserum therapy, he generously gave of his time to make antiserum available to the practicing physicians of New England. His efforts are crisply recorded

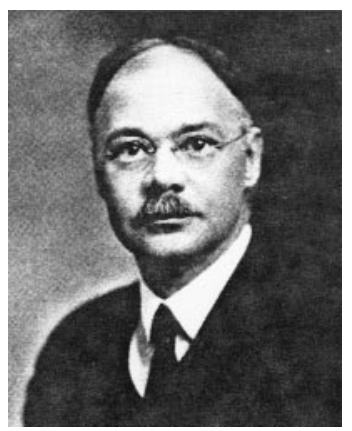
in two handbooks, one on serum therapy and the other on serum therapy and chemotherapy written in conjunction with Roderick Heffron of the Massachusetts Department of Public Health and published by the Commonwealth Fund. His work with pneumonia ran parallel to his longstanding interest in tuberculosis. For years he was president of the Channing Home, one of the first special hospitals in Boston for the care of unfortunates with advanced tuberculosis. He also served faithfully on advisory committees of the Massachusetts and Boston City Health Departments.

Fred Lord was very much interested in postgraduate teaching and for years conducted at his home a weekly evening group discussion of some clinical problem. Although designed for small groups, so popular were these sessions that as many as 100 were enrolled in the course at one time. At an academic level, he percolated slowly up through the ranks as was the Harvard way, eventually becoming clinical professor of medicine, emeritus. Like many chest physicians, he was a highly skilled teacher of physical diagnosis, impressing no less a person than William B. Castle with his uncanny ability to percuss out small areas of consolidation-later confirmed by radiography. It is interesting that for his presidential address before the AATS he chose to describe and discuss the finer points of the physical diagnosis of bronchial stenosis.

During World War I he was on almost continuous hospital duty at home, interrupted in the fall of 1917 by service with the American Red Cross Commission to Serbia with the assimilated rank of major. He and his colleagues were recognized by the Crown Prince with the Serbian Red Cross at Corfu and by the second order of St Sava at Salonika. Both decorations are preserved in the Rare Books section of the Countway Library at Harvard.

Photograph courtesy of the Harvard University Archives. 
Frederick Taylor Lord was well described by his colleagues, James H. Means and Francis M. Rackemann in the Annals of Internal Medicine after his death on November 4, 1941, 3 months after the death of his wife. At one time he was a member of the American Society for Clinical Investigation, the American Clinical and Climatological Association, the Interurban Clinical Club, the National Tuberculosis Association, and, of course, The American Association for Thoracic Surgery (president, 1932). Basically, his colleagues point to a life of quiet and sustained devotion to his professional work and to his family and friends. His point of view toward medicine was that of scholar and teacher, always seek- ing to make what he had learned available to others. He left behind many students grateful for his wise counsel, for the example of meticulous thoroughness that he set, and for the kindly friendship with those who shared his work. He possessed those qualities that are said to be necessary to the working of democracy - humility, humanity, and humor. The last of these was often manifested by a twinkle in his eye of almost elfin jollity. J.H.P., in The New England Journal of Medicine, wrote: "He talked little and did much. He was a true scholar and scientist, a physician without guile."

J. Gordon Scannell, MD 